顎矯正手術のリスクマネージメントにおけるクリニカルパスの役割

一当科におけるクリニカルパスの改訂を通して一

1 都立大塚病院口腔科, ${ }^{2}$ 都立府中病院歯科口腔外科, ${ }^{3}$ 東京歯科大学口腔外科学講座

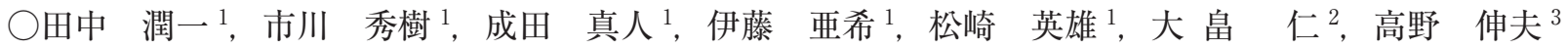

顎矯正手術は比較的定型的な手術・入院管理を行うことから, 口腔外科領域において最もクリニカルパスに 適していると考えられる。しかし, 本手術は患者選択度の高い手術であることから, りり安全であることが求 められる。一般にリスクマネージメントすなわち医療安全の質の向上を考えた際，漠然と問題点を捉えるより 具体的な項目に対して対策を講じるべきであることは疑う余地もない。そこで，顎矯正手術患者の入院・手術 管理において，逸脱症例やヴァリアンスなどから具体的な問題が指摘されるクリニカルパスが，どのようにリ スクマネージメントに係るかについて検討した。

対象は, LF I + SSRO : 49 例, SSRO : 247 例, その他 : 20 例の顎矯正手術を施行したクリニカルパス患者 316 症例で，パス逸脱の原因とヴァリアンス結果，さらに看護師に対するアンケート調査結果を分析した。

その結果，それぞれにみられた具体的な問題点についてクリニカルパスを改訂することで，入院期間，手 術・麻酔法, 術直後管理などについて改良を加えることができた。

クリニカルパスでは，逸脱症例やヴァリアンスが生じることから問題点が具体化される。一方リスクマネー ジメントでは，抽象的に問題を取り上げるよりも具現化された項目に対して対策を講じる方が効果的である。 したがって，クリニカルパスのヴァリアンスなどによって具現化された問題点を 1 つずつ改善してクリニカル パスを改訂することが, リスクマネージメントに直結するものと考えられた。

下顎前突症患者に対する上下顎移動術後の顎骨安定性について 一骨接合にチタンミニプレートを使用した群と PLLA 吸収性プレートを併用した群の比較一

新潟大学大学院医歯学総合研究科 顎顔面再建学講座 組織再建口腔外科学分野

永井 正紀, 小林 正治, 五島 秀樹, 加納 浩之, 齊 藤 力

【目的】下顎前突症に対する上下顎移動術の骨接合にチタンミニプレートのみを使用した群と PLLA プレート を併用した群の術後の顎骨安定性を比較検討した。

【対象】上下顎骨移動術を施行した下顎前突症患者のうち資料の整った 108 名を対象とし, 上顎骨の骨接合に チタンミニプレートのみを使用した A 群 37 名と PLLA プレートを併用した B 群 71 名に分類した。

【方法】術前と術直後, 術後 6 か月以上経過時に撮影した側面頭部 X 線規格写真を使用し, S 点を原点, FH 平面に平行な直線を $\mathrm{X}$ 軸，それに直交する直線を $\mathrm{Y}$ 軸とした座標系で，上顎骨と下顎骨の位置の水平的およ び垂直的変化量を算出した。

【結果および考察】 $\mathrm{A}$ 点における手術時前方移動量は $\mathrm{A}$ 群が $2.4 \mathrm{~mm}, \mathrm{~B}$ 群が $1.5 \mathrm{~mm}$ で, 術後の変化量はそれ ぞれ前方に $0.2 \mathrm{~mm}$, 後方に $0.1 \mathrm{~mm}$ であった。 $\mathrm{A}$ 点における垂直方向の手術時移動量は, $\mathrm{A}$ 群が下方に $0.1 \mathrm{~mm}$, $\mathrm{B}$ 群が $0 \mathrm{~mm}$ で，術後の変化量はそれぞれ上方に $0.5 \mathrm{~mm}$ と $0.4 \mathrm{~mm}$ であった。 $\mathrm{B}$ 点における手術時後方移動量 は $\mathrm{A}$ 群が $5.7 \mathrm{~mm}$, B 群が $5.4 \mathrm{~mm}$ で，術後の変化量はそれぞれ前方に $0.7 \mathrm{~mm}$ と $0.6 \mathrm{~mm}$ であった。B点におけ る手術時上方移動量は $\mathrm{A}$ 群が $1.7 \mathrm{~mm}, \mathrm{~B}$ 群が $1.1 \mathrm{~mm}$ で, 術後の変化量はそれぞれ上方に $0.4 \mathrm{~mm}$ と $0.6 \mathrm{~mm}$ であっ た。手術時移動量と術後変化量の関係を調べたところ，水平方向では両群とも上顎骨ならびに下顎骨ともに負 の相関関係が認められたが，垂直方向ではA 群で上顎骨ならびに下顎骨ともに相関関係は認められなかった ものの，B 群で負の相関関係が認められた。今後は, 顎骨の移動量や移動方向を考慮しながら，顎知正手術に おける PLLA プレートの適応範囲を広げていきたいと考えている。

【結論】両群の術後の顎骨安定性に差は認められず, 手術時移動量が大きいほど元の位置に戻ろうとする術後 変化が生じやすかった。 
超音波画像を用いた片側性口唇裂・口蓋裂症例に対する上顎骨延長術後の骨形成の評価

${ }^{1}$ 東京医科歯科大学大学院医歯学総合研究科 顎顔面頸部機能再建学系 顎顔面機能修復学講座 顎顔面矯正学分野, ${ }^{2}$ 東京医科歯科大学 大学院医歯学総合研究科口腔機能再構築学系 口腔機能再建学講座 口䏶放射線医学分野

片岡 恵一 ${ }^{1}$, 馬場 祥行 ${ }^{1}$, 本 田 綾 ${ }^{1}$, 石 崎 敬 ${ }^{1}$, 鉄村 明美 ${ }^{2}$, 大林 尚人 ${ }^{2}$, 倉 林 亨 ${ }^{2}$, 鈴木 聖一 1 , 森山 啓司 ${ }^{1}$

【目的】近年, 口唇・口盍裂患者の外科的矯正治療において上顎骨延長法が選択されることが多い。当分野で は，骨延長術後の骨形成の評価の際に，X線被曝を最小限とする目的で，超音波画像診断の有用性について検 討してきた。その結果, 上顎洞前壁の骨形成について，超音波画像では CT と同様の所見が得られることを過 去に報告した。今回我々は，骨延長後の長期経過症例における骨延長部の骨形成および骨改造の様相を観察す るために超音波画像を用いた評価を行った。【方法】 RED システムによる上顎骨延長術を適用した片側性口唇 口蓋裂患者 7 名（骨延長術後 2 年 3 か月から 6 年 11 か月， 上顎前方移動量 $7.5 \mathrm{~mm}$ から $17.5 \mathrm{~mm}$ ）の超音波画 像診断を行った。超音波画像診断には B モード $(14 \mathrm{MHz})$ を用い，上顎洞前壁の Le Fort I 型骨切り線相当 部の皮膚上でプローブを垂直にあてて行った。得られた画像より，骨形成および骨改造の評価のために，延長 部の皮質骨の連続性と上顎骨延長術により生じた延長部のステップを左右側について評価した。【結果】皮質 骨の連続性については，十分な連続性が確認されたものが 6 名，確認されないものが 1 名であった。一方，上 顎骨延長術により生じた延長部のステップに関しては，両側ともにステップが明瞭なもの 4 名，片側が明瞭で もう一方が明瞭なステップではないが延長部のステップとして認識できるもの 2 名, 両側ともに不明瞭なもの が1名であった。【結論】超音波画像を用いることにより，上顎骨延長術を適用した症例の骨形成の評価をチェ アサイドにてX 線の被曝なく簡便に行うことが可能であった。長期経過症例における骨形成や骨改造の多様 性は，長期間にわたる術後のモニタリングの必要性を示唆するものである。

\section{片側性顎関節内障患者における顔貌と顎関節病態との関連性 一正貌硬・軟組織における対称性評価一}

昭和大学歯学部 歯科矯正学教室

鄭＼cjkstart勝 榮, 渋澤 龍之, 中山真由子, 藤川 泰成, 森田 明子, 槇 宏太郎

目的：近年，咬合ならびに顔貌の改善を目的とし矯正科を受診する患者は少なくない。外科的矯正治療のボー ダーラインケースにおいて, その改善を矯正治療単独で行うかあるいは外科的矯正治療の適応とするかは難し い問題であり，その治療方針の決定に際しては治療後の顔貌が重要な一要因となる。また，下顎骨の後退や顎 顔面の非対称などの形態的特徵と顎関節内障との関連性が報告されており，特に顔面の非対称を伴う下顎側方 偏位症例などは矯正治療後の安定性を左右する片側性顎関節内障の発現率が高く, 顎変形症の後天的要因とし て注目されている変形性関節症を伴っていることもめずらしくない。したがって，顔面非対称患者の治療方針 の設定に際しては，顎関節についての詳細な検査が必須であり，顎関節の状態が顔貌に対してどのような影響 を及ぼているのか, 十分に把握した上で治療方針の設定をおこなう必要性がある。そこで, 今回われわれ は，顎関節内障と顔貌の非対称との関連性を調査することとした。

方法：32 名（男性 9 名 女性 23 名）の片側性顎関節内障患者平均年令 25.6 歳（15 歳〜 40 歳）を対象とし, 顎関節病態を特定するためにそれぞれの対象について MRI を撮像した。正貌顔面規格写真および正面頭部 X 線規格写真の角度および距離計測を行い, 硬・軟組織非対称の相関性を検定した。さらに, 顎関節病態と顔面 の非対称との相関性を検討した。

結果：片側性顎関節内障患者において軟組織非対称と骨格形態の非対称の間，ならびに顎関節内障の病態と軟 組織非対称および骨格形態の非対称との間には有意な正の相関が認められた。

考察：本研究より顎関節内障の進行とともに顔貌の非対称性が増悪する可能性が示され, 顔面非対称患者の歯 科矯正治療方針の設定には，顎関節の影響を十分認識し，顎関節に対する適切な診査，診断が必要であると考 えた。 